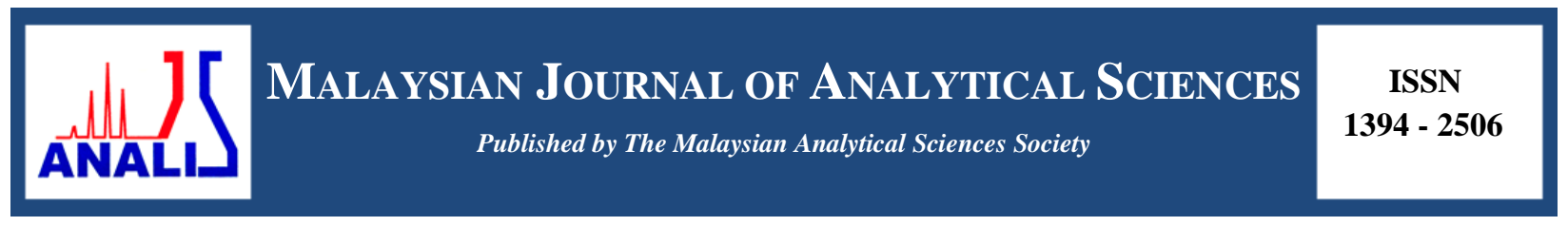

\title{
CRITICAL POWDER LOADING AND RHEOLOGICAL PROPERTIES OF POLYPROPYLENE/GRAPHITE COMPOSITE FEEDSTOCK FOR BIPOLAR PLATE APPLICATION
}

\author{
(Beban Serbuk Kritikal dan Sifat Reologi Bahan Suapan Komposit Polipropilena/Grafit untuk \\ Aplikasi Plat Dwikutub) \\ Iswandi $^{1,2,3}$, Jaafar Sahari ${ }^{1,2}$, Abu Bakar Sulong ${ }^{1,2}$, Teuku Husaini ${ }^{1}{ }^{*}$ \\ ${ }^{1}$ Fuel Cell Institute \\ ${ }^{2}$ Department Mechanical and Materials Engineering, Faculty of Engineering and Built Environment \\ Universiti Kebangsaan Malaysia, 43600 UKM Bangi, Selangor, Malaysia \\ ${ }^{3}$ Department Mechanical Engineering, \\ Institut Teknologi Medan, Medan, Indonesia \\ *Corresponding author: t_husaini_st@yahoo.com
}

Received: 5 February 2016; Accepted: 22 April 2016

\begin{abstract}
Bipolar plate is one of the key parts in the fuel cell technology with the advantages of a higher electrical conductivity and mechanical properties are high. Injection molding is one of the manufacturing method that being used in the manufacture of bipolar plates. The critical powder loading and rheological properties of the feedstock are an important factor in the process of injection molding in the manufacturing process of bipolar plate. The critical powder loading feedstocks with a mixture of polypropylene and graphite have been conducted with the torque method test. The appropriate critical powder loading the using a graphite filler material was produced with the composition of $75 \%$ the weight of an optimum load and $25 \%$ weight of polypropylene. The rheological studies have also been carried out using capillary test for determining critical loading powder by increasing the viscosity of the feedstock. The test results showed that the rheological properties of the feedstock with optimum powder loading to exhibit pseudoplastic properties are suitable for injection molding process with the $\mathrm{n}$ less than one.
\end{abstract}

Keywords: injection molding, polymer composite, bipolar plate, fuel cell

\section{Abstrak}

Plat dwikutub adalah salah satu bahagian utama pada teknologi sel bahanapi dengan kelebihan sifat kekonduksian elektrik dan mekanik yang tinggi. Pengacuan suntikan adalah salah satu kaedah pembuatan yang digunakan dalam pembuatan plat dwikutub. Pembebanan serbuk genting dan sifat reologi bahan suapan adalah faktor penting dalam proses pengacuan suntikan semasa proses pembuatan plat dwikutub. Pembebanan serbuk genting bahan suapan dengan campuran polipropilina dan grafit telah pun dijalankan dengan kaedah ujian nilai tork. Pembebanan serbuk genting yang sesuai menggunakan bahan suapan grafit telah dihasilkan dengan komposisi $75 \%$ berat yang merupakan beban optimum dan $25 \%$ berat polipropilena. Kajian reologi juga telah dijalankan menggunakan ujian rerambut bagi menentukan beban serbuk genting dengan peningkatan nilai kelikatan bahan suapan. Keputusan ujian sifat reologi didapati bahawa bahan suapan dengan beban serbuk optimal mempamerkan sifat pseudoplastik yang sesuai bagi proses pengacuanan suntikan dengan nilai $n$ kurang daripada 1 .

Kata kunci: pengacuan suntikan, komposit polimer, plat dwikutub, sel bahanapi 


\title{
Iswandi et al: CRITICAL POWDER LOADING AND RHEOLOGICAL PROPERTIES OF POLYPROPYLENE/GRAPHITE COMPOSITE FEEDSTOCK FOR BIPOLAR PLATE APPLICATION
}

\begin{abstract}
Introduction
Conductive polymer composite (CPC) materials generally comprise a mixture of polymers and conductive fillers, such as carbon-based and metallic fillers. Conductive materials contribute to the improvement of electrical and mechanical properties (e.g., critical load) of a material, particularly for carbon-based materials, such as graphite (G), carbon black (CB), carbon nanotubes, and carbon fiber (CF) [1 - 3]. One of the applications of CPC is the bipolar plate, which requires high electrical conductivity for electron mobility. The properties of CPC materials favor their application in the manufacture of bipolar plates. Among various carbon-based fillers, graphite is the optimal material type because of its chemical stability [4], corrosion resistance [4], lightness [5 - 8], and high electrical conductivity [9]. Achieving the required properties when such materials are utilized depends on the manufacturing method. Compression and injection molding are two of the most commonly used methods to fabricate bipolar plates. Injection molding has an advantage over compression molding when used for mass production; injection molding has better factor cycle time and compact ability during production than compression molding. Several factors, such as process parameters, contribute to the success of the manufacturing process. However, the most important factors are the characteristics that correspond to the properties of the feedstock. Feedstock injection molding is a balanced blend of filler powder and binder matrix. Three important factors influence powder loading injection molding; these three factors are the rheological properties of a good feedstock for production, mechanical properties of the materials, and tight dimensional control and limited distortion [10].
\end{abstract}

A number of studies have been conducted to determine the load range of the feed for the powder filler material. Generally, ceramic powder carbon-based filler is the material used; it is injected at a load range of $50 \%$ to $55 \%$ by volume. Previous studies [11 - 13] have indicated that the appropriate critical load could be up to $65 \%$ by volume. Other studies have reported the use of alumina powder as filler at feedstock composition of $80.5 \mathrm{wt} \%$ filler (50\% by volume) [14]. Feedstock with different types of metals as fillers are commonly injected during powder loading at $56 \%[15,16]$ to $60 \%$ by volume $[17,18]$. Injection of fillers such as $\mathrm{G}, \mathrm{CB}$, and CF has also been successfully conducted at filler composition of up to $60 \%$ by weight [19]. The load volume of feedstock refers to critical filler loads in the feedstock up to the maximum that can be injected. An increase in the volume load of feedstock affects feedstock viscosity [20]. Relative changes in viscosity influence critical powder loading. Feedstock viscosity is highly dependent on particle size, particle size distribution, solid loading, and specific surface area [21]. A study has demonstrated through modeling that powder load is influenced by particle size distribution [22]. Studying the critical powder loading feedstock of polypropylene (PP)/G is necessary to determine the maximum powder load of $\mathrm{G}$ fill in the appropriate feedstock injection molding process. A detailed investigation of the maximum powder loading of this feedstock has never been conducted.

The current study investigates the critical powder load by using mixer torque variations and analyzing the viscosity behavior of $G$ feedstock. Rheological analysis with various $G$ fillers was conducted on the composition of the feedstock to determine the feedstock's pseudo-plastic nature and mold reliability.

\section{Materials and Methods}

A matrix polypropylene (PP) (injection molding grade, impact copolymer SM 240) with a melting point of $160{ }^{\circ} \mathrm{C}$ to $170{ }^{\circ} \mathrm{C}$, density of $0.9 \mathrm{~g} \mathrm{~cm}^{-1}$, and MFR of $10 \mathrm{~g} / 10 \mathrm{~min}$ was utilized. PP allows for balance between stiffness and impact resistance. PP was purchased from Polypropylene Malaysia Sdn. Bhd. Natural G was obtained from Asbury of 3243 (99\% purity, $44 \mu \mathrm{m}$ average normal powder size, $3 \mathrm{~m}^{2} \mathrm{gr}^{-1}$ surface area, $27.8 \mathrm{~S} \mathrm{~cm}^{-1}$ electrical conductivity, and $2.31 \mathrm{~kg} \mathrm{~m}^{-3}$ density); the technical aspects of the utilized natural $\mathrm{G}$ were provided by the supplier. The morphology of the G powder was observed with a scanning electron microscope (SEM; Zeis EVO MA10). The morphology of graphite filler is important to know the effects that occur during the test (Figure 1).

Figure 1 show that the morphology of natural graphite flakes has different shapes and sizes. Shaped pieces of $G$ particles have better electrical properties than others in the form of a sphere [23, 24]. The process of mixing the powder and testing the critical powder loading (G and binder PP) was performed with an internal mixer (Haake Remix Roller rotor type 600R with Haake Polylab TM programming). The PP melt was mixed in a chamber at a volume of $50 \mathrm{~cm}^{3}$ and filler composition of $60 \mathrm{wt} . \%$ to 80 wt. \% of graphite. The mixing parameters were $200{ }^{\circ} \mathrm{C}$ and $50 \mathrm{rpm}$ for 2 hours. The experimental torque values were observed and found to be unstable [24]. Feedstock viscosity was measured with a Shimadzu capillary rheometer (CFT 500D) with a capillary diameter $(D)$ of $0.1 \mathrm{~cm}$, 
length $(L)$ of $1 \mathrm{~cm}$, and $L / D$ of 10 at $160{ }^{\circ} \mathrm{C}$. The measurement was done at a temperature of melts viscosity of the feedstock with a given load and power passing through the capillary.

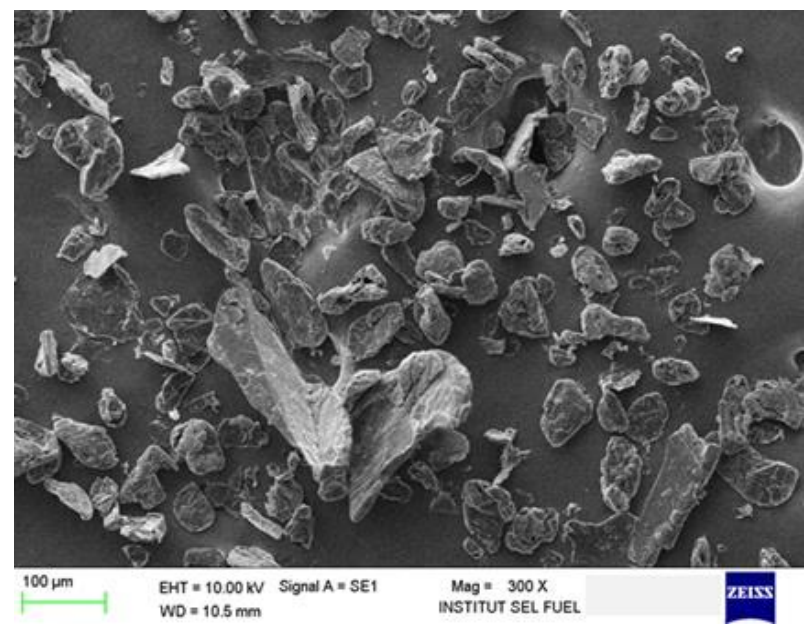

Figure 1. Morphology of graphite powder

\section{Results and Discussion}

Critical powder loading was determined by observing the changes in the value of the torque variations (critical solid loadings) of the $\mathrm{G}$ feedstock. Generally, with the increase in filler material content during the process, torque slowly increased during mixing until an unstable condition was reached. The results in (Figure 2) show an increase in torque blending at $80 \mathrm{wt}$. $\%$ of the powder filler. The blending process became uncertain after this increase. Torque did not reach a steady state and fluctuated instead. These results indicate that the critical load mix was approximately $75 \mathrm{wt}$. \% of the filler powder. These results are similar to those of ceramic-based materials and metals reported in [13] at $80.5 \mathrm{wt}$ \% of filler. In this study the critical powder loading test has been carried out three times the test at between 139 minutes to 142 minutes. Based on observations of time tests showed phenomenal torque value changes are likely the same, at $80 \%$ by weight graphite. This situation showed that the increase in the torque tends to depend on the content of graphite powder filler. The feedstock includes G filler with different particle sizes. The particle size distribution was shown in (Figure 3), which illustrates the variations in particle size and percentage of different feedstock. The differences in particle size were divided into small-sized [d(0.1): 18.85 $\mu \mathrm{m}]$, mean- or mid-sized [d(0.5): $56.43 \mu \mathrm{m}$ ], and large-sized [d(0.9): $127.08 \mu \mathrm{m}]$.

Particle sizes have a significant impact on critical powder load, where the amount of large particles that result in high critical loading filler is large $[10,25]$. The consolidation of particles with various sizes in the feed material affects density. In particular, the composition of the dominant particle size in the feedstock material has a significant effect on density. Small particles can be added to fill the empty spaces between large particles to increase density $[17,18]$. The particle size of the powder filler affects the determination of density and maximum aspect ratio of the feedstock [26]. During the blending process, the powder particles are arranged according to shape and size to achieve a stable level because neither the blending process nor excessive pressure can force particles to enter a dense compound [27, 28]. High packing densities can be achieved if the particle size is not uniform [27, 28]. The gap that forms between coarse particles because of restructuring allows the entry of a large number of fine particles, thereby contributing to the density of the random feedstock. Critical powder loading is also influenced by particle size, and density affects size variation, as shown in the feedstock schematic in (Figure 3). Based on SEM observation on the composition of $75 \%$ by weight graphite was found that the structure of graphite flakes form more compact. This condition is known of the composition of the particles homogeneously mixed to form a bond between the particle size large, medium and small. The other factor is the flakes particles very easily formed a solid 
Iswandi et al: CRITICAL POWDER LOADING AND RHEOLOGICAL PROPERTIES OF

POLYPROPYLENE/GRAPHITE COMPOSITE FEEDSTOCK FOR BIPOLAR PLATE

APPLICATION

structure as shown in (Figure 4). In a simple illustration of the bond between the graphite particles with different sizes are shown in (Figure 5).

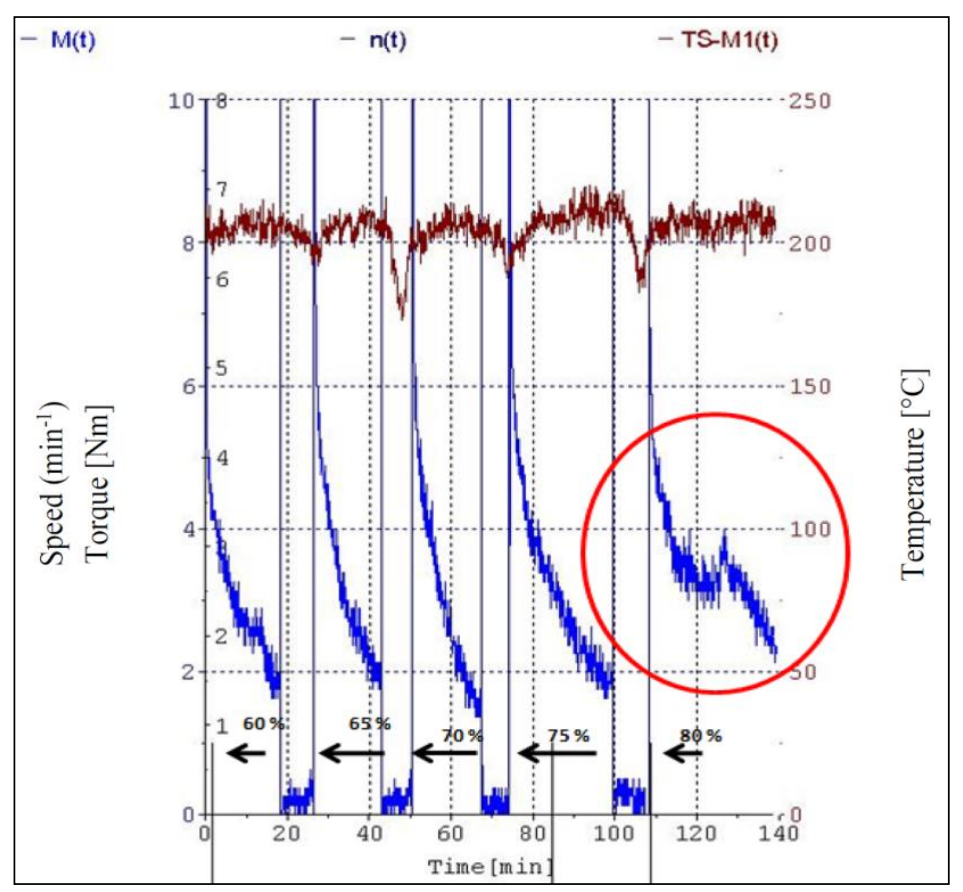

Figure 2. Effect of power loading on torque and temperature

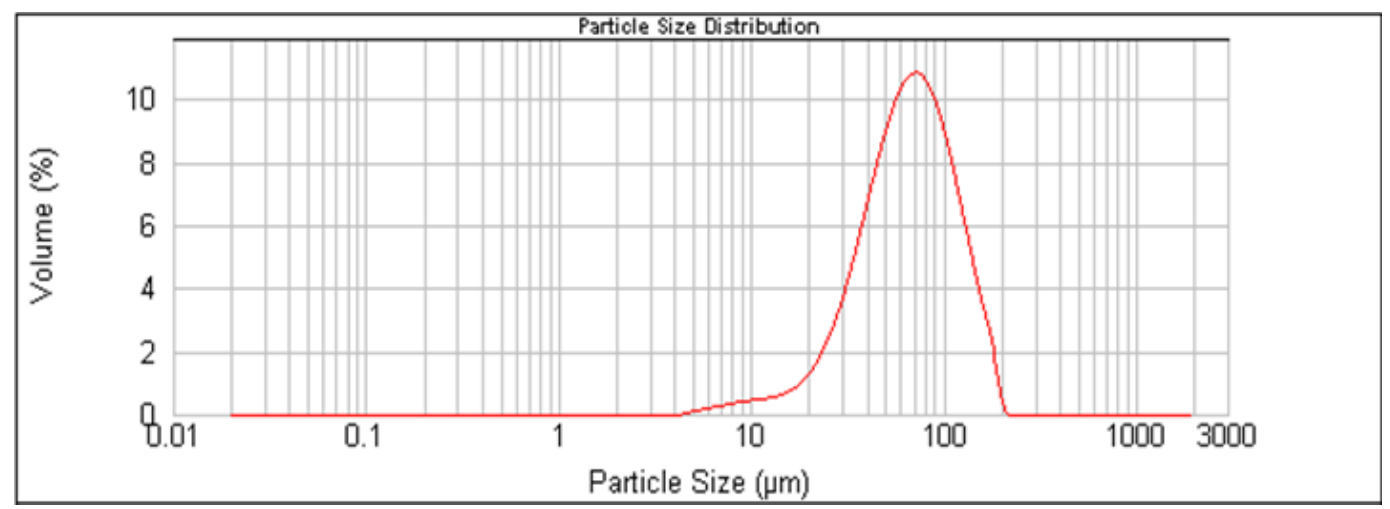

Figure 3. Particle size distribution of graphite 

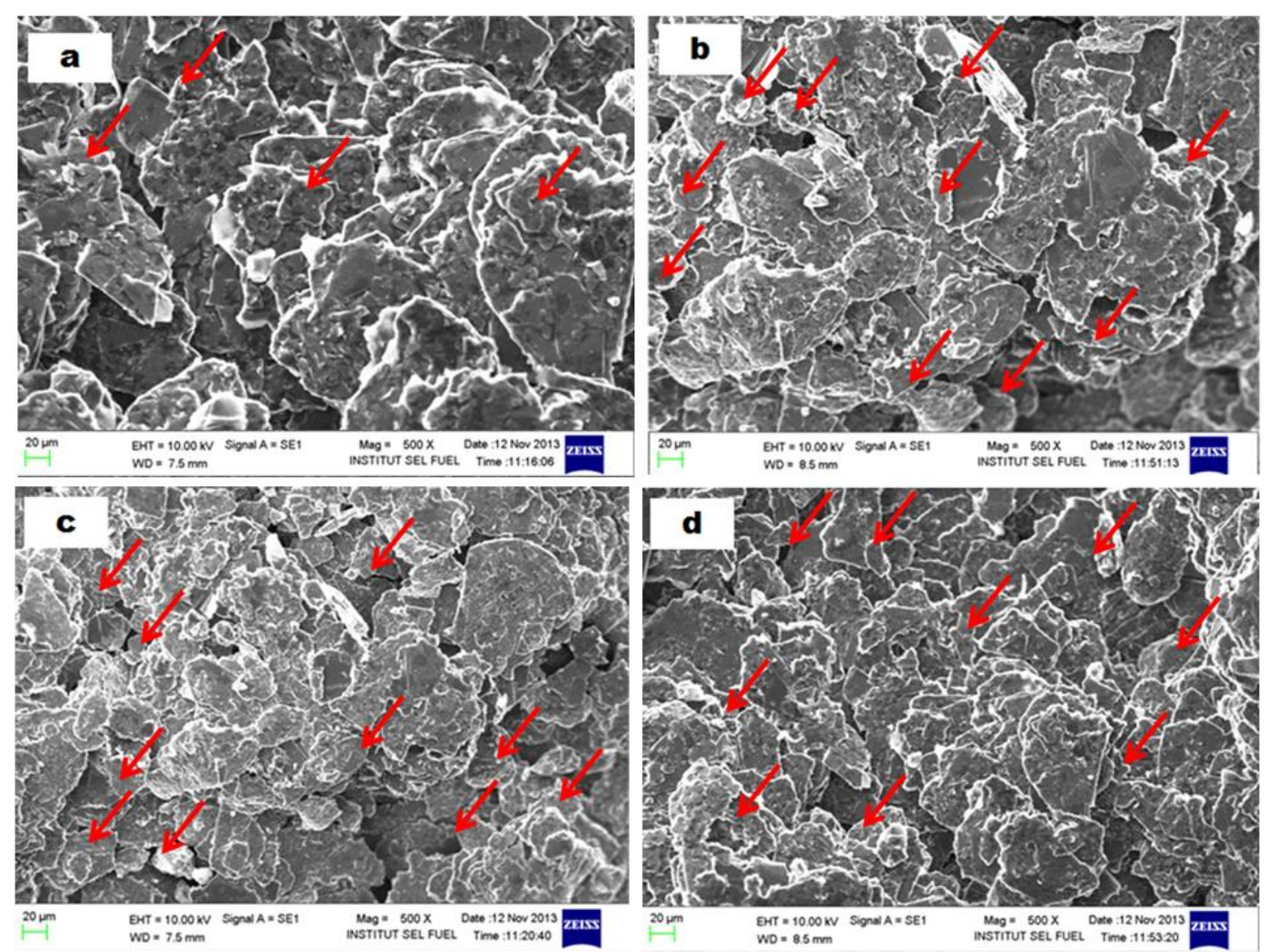

Figure 4. SEM of G feedstock (a) 60 wt.\%, (b) 65 wt. $\%$, (c) 70 wt.\%, and (d) 75 wt.\%

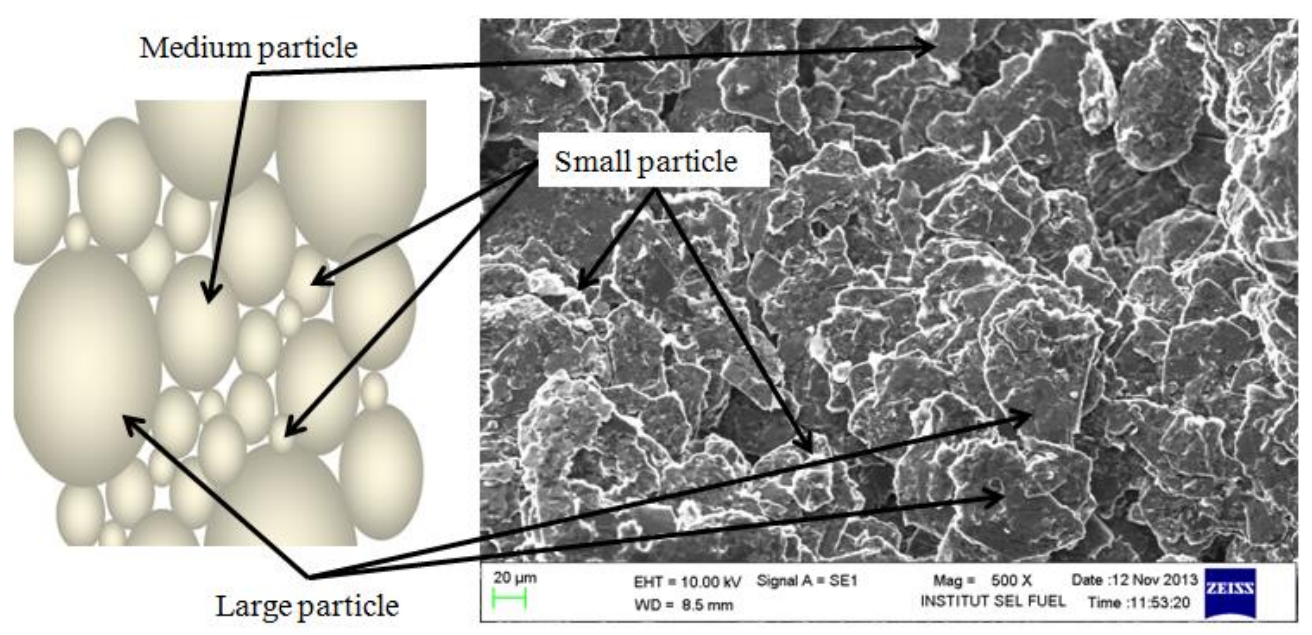

Figure 5. Schematic of different graphite particle sizes

The results of the viscosity test indicated an increase in viscosity versus the shear rate at the maximum filler powder content of $75 \mathrm{wt}$ \% (Figure 6). The increase in viscosity was inversely proportional to the increase in shear rate. 
Iswandi et al: CRITICAL POWDER LOADING AND RHEOLOGICAL PROPERTIES OF

POLYPROPYLENE/GRAPHITE COMPOSITE FEEDSTOCK FOR BIPOLAR PLATE

APPLICATION

This finding is consistent with that of previous studies $[17,18]$ and thus reveals that the materials that are pseudoplastic using the PIM process.

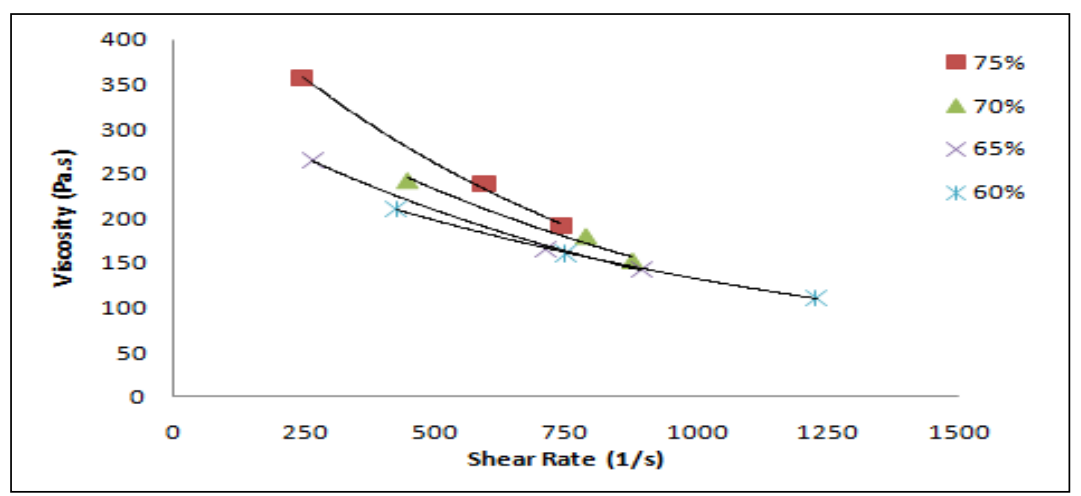

Figure 6. Feedstock viscosity versus shear rate at different powder loadings

The increase in feedstock viscosity was also affected by the increase in surface area, which occurred because of the increase in small particle variations in the filler. The improved composition of small particles simultaneously increased the surface area and caused agglomeration, which increased feedstock viscosity. The agglomeration in the feedstock fine powder formed a bond between the powders. This phenomenon occurs naturally because of the force of attraction between the surfaces of particles with varying strengths. The agglomeration of small particles in the feedstock is difficult to overcome [29]. Previous studies on critical powder loading using $G$ do not exist; nevertheless, this phenomenon shows similarities with the viscosity of ceramic feedstock because the use of solid powder materials and polymers as ceramic composite has the same characteristics as mixed feedstock. Studies that dealt with this phenomenon reported that the increase in surface area in feedstock containing $\mathrm{ZrO}_{2}$ and polymer ethylene-vinyl acetate copolymer grade at feedstock composition of $20 \mathrm{vol} . \%$ to $50 \mathrm{vol} \%$ ceramic powder has an impact on lowering the activation energy flow [29]. High shear rate at low powder load shows more polymer components than filler components. Viscosity and shear rate suitable for injection molding have already been reported in numerous studies. Studies recommend maximum viscosity of 1,000 Pa.s and shear rate in the range of $100 \mathrm{~s}^{-1}$ to $100,000 \mathrm{~s}^{-1}[27,29]$. The results of rheological studies on feedstock PP/G in the present study indicate viscosity at $80 \mathrm{~Pa}$.s. The shear rate is below the level allowed for injection molding processing $\left(1,700 \mathrm{~s}^{-1}\right)$. The test results show that feedstock viscosity and shear rate are generally within the range suitable for injection molding. The variations in viscosity caused by temperature at different powder loadings are shown in (Figure 7). A high load is required when the powder has high viscosity. Viscosity decreased when the feedstock temperature increased. By contrast, an increase in viscosity reduced the shear rate, as shown in (Figure 6). The increase in viscosity is anticipated because of the increase in powder filler content consisting of fine powder agglomeration. Devaluation of viscosity occurs when the percentage content of fine powder is low. Increasing the coarse powder content reduces feedstock agglomeration [30, 31]. Changing on the different powder loading results in a change in feedstock shear rate. Similar conditions were observed during injection molding, wherein shear rate was applied to the material at a given pressure value. The ratio between the filler and matrix polymer powder is significant to the success of the current and subsequent processes.

High powder loading makes it easy to control the dimensions. An extremely high powder loading (very small binder matrix) produces a mixture with remarkably high viscosity, which could complicate the injection molding process $[10,27]$. The critical composition of the powder mixture can be achieved by reducing the concentration of the polymer matrix. Reduction of the polymer matrix concentration also sets the highest filler powder loading. When the powder loading exceeds the critical limit, the viscosity of the mixture becomes extremely high [32]. The results of the mean flow index behavior, $n$, for all compositions show that all feed materials exhibit a pseudo-plastic behavior (Table 1.). The value of $n$ indicates the uniformity of the flow of a mixture in the capillary during testing 
$[30,31]$. The decrease in the viscosity of pseudo-plastic materials with the increase in shear rate was noticeable at a low powder load. The $\mathrm{n}$ value was less than 1 , which indicates that the feed material exhibits shear thinning. A feedstock should have an $n$ value of less than 1 during injection molding [29].

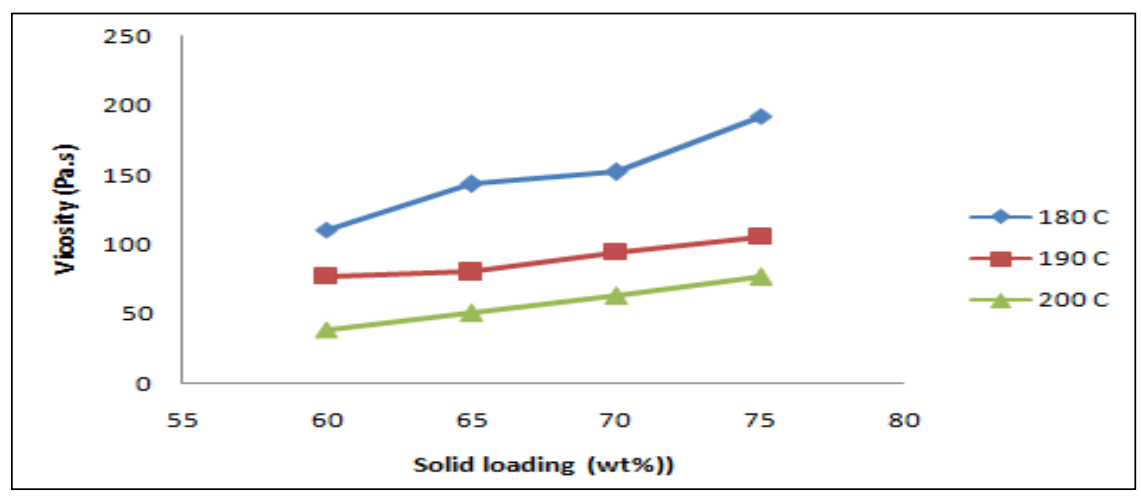

Figure 7. Relationship between feedstock viscosity and different powder loading temperatures

Table 1. Rheological properties of feedstock at a filler content of $60 \mathrm{wt} . \%$ to $75 \mathrm{wt}$. \%

\begin{tabular}{ccccc}
\hline Feedstock wt. \% & Temperature & $\mathbf{E}(\mathbf{k J} / \mathbf{m o l})$ & $\boldsymbol{n}$ value & $\boldsymbol{\alpha}$ \\
\hline 60 & 180 & 93.412 & 0.377 & 501.83 \\
& 190 & 93.412 & 0.415 & 616.35 \\
& 200 & 93.412 & 0.301 & 1610.85 \\
65 & 180 & 92.731 & 0.295 & 440.70 \\
& 190 & 92.731 & 0.348 & 727.32 \\
& 200 & 92.731 & 0.323 & 1196.08 \\
70 & 180 & 78.937 & 0.521 & 331.49 \\
& 190 & 78.937 & 0.285 & 796.74 \\
& 200 & 78.937 & 0.444 & 932.04 \\
75 & 180 & 82.146 & 0.331 & 352.30 \\
& 190 & 82.146 & 0.312 & 660.47 \\
& 200 & 82.146 & 0.366 & 837.11 \\
\hline
\end{tabular}

The ability of feedstock containing high $\mathrm{G}$ filler to flow during injection molding is indicated by the value of $\mathrm{n}$, which should be small. The effect of increasing load on the feedstock powder through injection can be obtained by developing the relationship between particle and particle bonding in the composite. The value of $n$ is obtained with Equation (1) [27, 29] as follows:

$$
\tau-\tau_{y}=k(\gamma)^{n}
$$

The calculation of the $\mathrm{n}$ value and moldability $\alpha$ shown in Table 1., where $\mathrm{n}$ is the average resulting from the composition of $60 \mathrm{wt}$. \% to $75 \mathrm{wt}$. \% of G filler, shows that $\mathrm{n}$ is smaller or less than 1 . This situation proves that the feedstock is pseudoplastic and that qualified feedstock can be injected because of flow ability. The determination of moldability index value $(\alpha)$ is an important method to predict the suitability of an material for the injection molding 


\section{Iswandi et al: CRITICAL POWDER LOADING AND RHEOLOGICAL PROPERTIES OF POLYPROPYLENE/GRAPHITE COMPOSITE FEEDSTOCK FOR BIPOLAR PLATE APPLICATION}

process as shown in Table 1. The result of the calculation shows that the largest value at $200{ }^{\circ} \mathrm{C}$ for each weight percent graphite filler. It means the larger values of moldability, the more easily feedstock was provided by the injection molding process [18, 27]. The activation energy (E) of a feedstock is strongly related to its viscosity [33]. An improvement in viscosity significantly affects the rate of increase of the activation energy value. This relationship occurs because of the different particle sizes arranged in the feedstock. In this study, a parallel increase in viscosity was observed with the addition of the filler material into the feedstock. The difference in the composition of fine- and large-sized particles contributed to the changes in viscosity. Another factor that affected the increase in viscosity was the content and composition of small particles. These results are consistent with the findings on microstructures because viscosity increased in a parallel manner with the increase in G filler content at a composition of 60 wt. $\%$ to 75 wt. \%.

The composition of in-sized particles also improved when density was increased, resulting in an increase in viscosity. The obtained SEM images show an increase in small-sized particle content in the feedstock. Studies on the effect of size on viscosity have shown that a feedstock mixture with fine-sized particles has a higher melting point than that with large-sized particles. Different particle sizes also influence the temperature of the process; finesized particles are more likely to increase the temperature of the process compared with rough-sized particles [30, 31]. The differences in the activation energy values (shown in Table 1) are due to the thermal expansion between the components of the material; this expansion occurred because of differences in particle size and agglomeration in the fine particles. This phenomenon occurred at $60 \mathrm{wt} . \%$ and 65 wt. \% of graphite. Furthermore, activation energy was affected by the decrease and increase in $\mathrm{G}$ content (wt. \%). Graphite powder dispersion between small and large particle sizes was evenly distributed. Nevertheless, agglomeration should occur between particle dispersion on small particle sizes to increase the activation energy, as shown at $70 \mathrm{wt} . \% \mathrm{G}$ and $75 \mathrm{wt} . \%$ of graphite. This condition will increase the interaction among various particle sizes so that feedstock viscosity can increase. The viscosity of the obtained feedstock was still acceptable because the injection provided $\mathrm{G}$ dispersion in a uniform feedstock, which resulted in an improved particle distribution network and electrical conductivity between the particle surface and various particle sizes. The mechanical properties of the composite materials were increased by the dispersion of particles with different sizes, which filled the gaps, thereby increasing density.

The microstructures of the feedstock are shown in Figure 4. Compaction with particle sizes was parallel to the increase in filler content in the feedstock from $60 \mathrm{wt}$. \% to $75 \mathrm{wt}$. \%. The improvement of G filler composition with different particle sizes indicated the potential for increased density. These results are supported by studies on the microstructures shown in (Figure 4) and indicate an increase in the content of small-sized particles that appeared to be more dispersed in the feedstock. The increase in the amount of small-sized particles significantly affected feedstock viscosity, as shown by the red arrows in (Figure 4(d)). The SEM observation shows the difference of the shape and size of particles in the presence of polypropylene as a binder, a white coat over the form of graphite. The decrease in filler content resulted in a decline in the dispersion of small-sized particles. The decrease in the amount of small-sized particles in the filler content is shown in (Figure 4(a)), which shows the composition of the filler content to be $60 \mathrm{wt}$ \% of graphite. These results are consistent with those obtained by Bobek et al. [34], who found that high packing densities can be achieved when particle size is not uniform. The variations in particle size are also shown in the schematic of particle size in (Figure 5).

The particle dispersion conditions in the blending process provide the opportunity to form porosity. An increase in porosity occurs when the filler content in the feedstock decreases slightly, instead of porosity reduction in feedstock occurring because of filler content increase. The increase in filler content with filler size variation denotes the possibility of small particles filling the gaps in the feedstock and ultimately reducing porosity. Dispersion of particles different sizes also showed homogeneous up to contribute to an increase in viscosity, in which the homogeneous properties is the important properties of the feedstock [35].

\section{Conclusion}

This study showed that a suitable feedstock composition determined by fitting should involve balance between the powder filler and binder matrix, particularly during injection molding. Critical solid loading of $75 \mathrm{wt}$. \% was found to be the optimal composition of the powder and binder; it affected the stability of the injection molding process. At the maximum critical load of $75 \mathrm{wt}$. \% of the filler, torque stability remained normal. At $80 \mathrm{wt}$ \% composition, 
torque became unstable. This situation suggests that an increase in maximum viscosity and is unsuitable for injection molding. High viscosity was caused by the density of the filler content compared with polymeric materials that serve as a binder in the filler. The differences in the size and composition of the powder particles increased viscosity significantly because solid particles increased the density of the feedstock powder. An improvement in density and viscosity affected the injection molding parameters such as injection pressure and flow of the feedstock.

\section{Acknowledgement}

The authors gratefully acknowledge the financial support provided for this work by the Malaysian Ministry of Higher Education under contract numbers DIP-2012-05, ERGS/1/2011/TK/UKM/01/20 and FRGS/1/2013/TK04/UKM/01/2.

\section{References}

1. Dicks, A. L. (2006). The role of carbon in fuel cells. Journal of Power Sources, 156(2): 128 - 141.

2. Heo, S. I., Oh, K. S., Yun, J. C., Jung, S. H., Yang, Y. C., and Han, K. S. (2007). Development of preform moulding technique using expanded graphite for proton exchange membrane fuel cell bipolar plates. Journal of Power Sources, 171(2): 396 - 403.

3. Dweiri, R. and Sahari, J. (2007). Electrical properties of carbon-based polypropylene composites for bipolar plates in polymer electrolyte membrane fuel cell (PEMFC). Journal of Power Sources, 171(2): 424 - 432.

4. Liao, S. H., Yen, C. Y., Weng, C. C., Lin, Y. F., Ma, C. C. M., Yang, C. H., Tsai, M. C., Yen, M. Y., Hsiao, M. C., Lee, S. J., Xie, X. F. and Hsiao, Y. H. (2008). Preparation and properties of carbon nanotube/polypropylene nanocomposite bipolar plates for polymer electrolyte membrane fuel cells. Journal of Power Sources, 185(2): $1225-1232$.

5. Derieth, T., Bandlamudi, G., Beckhaus, P., Kreuz, C., Mahlendorf, F., and Heinzel, A. (2008). Development of highly filled graphite compounds as bipolar plate materials for low and high temperature PEM fuel cells. Journal of New Materials for Electrochemical Systems, 11(1): 21 - 29.

6. Lee, J. H., Jang, Y. K., Hong, C. E., Kim, N. H., Li, P., and Lee, H. K. (2009). Effect of carbon fillers on properties of polymer composite bipolar plates of fuel cells. Journal of Power Sources, 193(2): 523 - 529.

7. Guo, N., and Leu, M. C. (2012). Effect of different graphite materials on the electrical conductivity and flexural strength of bipolar plates fabricated using selective laser sintering. International Journal of Hydrogen Energy, 37(4): $3558-3566$.

8. Taherian, R., Golikand, A. N. and Hadianfard, M. J. (2011). The effect of mold pressing pressure and composition on properties of nanocomposite bipolar plate for proton exchange membrane fuel cell. Materials \& Design, 32(7): 3883 - 3892.

9. Planes, E., Flandin, L., and Alberola, N. (2012). Polymer composites bipolar plates for PEMFCs. Energy Procedia, 20: $311-323$.

10. Agote, I., Odriozola, A., Gutierrez, M., Santamarıa, A., Quintanilla, J., Coupelle, P. and Soares, J. (2001). Rheological study of waste porcelain feedstocks for injection moulding. Journal of the European Ceramic Society, 21(16), $2843-2853$.

11. Reddy, J. J., Ravi, N. and Vijayakumar, M. (2000). A simple model for viscosity of powder injection moulding mixes with binder content above powder critical binder volume concentration. Journal of the European Ceramic Society, 20(12): $2183-2190$.

12. Baojun, Z., Xuanhui, Q., and Ying, T. (2002). Powder injection molding of WC-8\% Co tungsten cemented carbide. International Journal of Refractory Metals and Hard Materials, 20(5), 389 - 394.

13. Krauss, V. A., Pires, E. N., Klein, A. N., and Fredel, M. C. (2005). Rheological properties of alumina injection feedstocks. Materials Research, 8(2): $187-189$.

14. Loh, N. H., Tor, S. B. and Khor, K. A. (2001). Production of metal matrix composite part by powder injection molding. Journal of Materials Processing Technology, 108(3): 398 - 407.

15. Loebbecke, B., Knitter, R. and Haußelt, J. (2009). Rheological properties of alumina feedstocks for the lowpressure injection moulding process. Journal of the European Ceramic Society, 29(9): 1595 -1602.

16. Mighri, F., Huneault, M. A. and Champagne, M. F. (2004). Electrically conductive thermoplastic blends for injection and compression molding of bipolar plates in the fuel cell application. Polymer Engineering \& Science, 44(9): 1755 - 1765. 
Iswandi et al: CRITICAL POWDER LOADING AND RHEOLOGICAL PROPERTIES OF

POLYPROPYLENE/GRAPHITE COMPOSITE FEEDSTOCK FOR BIPOLAR PLATE

APPLICATION

17. Ahn, S., Park, S. J., Lee, S., Atre, S. V. and German, R. M. (2009). Effect of powders and binders on material properties and molding parameters in iron and stainless steel powder injection molding process. Powder Technology, 193(2): $162-169$.

18. Khakbiz, M., Simchi, A. and Bagheri, R. (2005). Analysis of the rheological behavior and stability of 316L stainless steel-TiC powder injection molding feedstock. Materials Science and Engineering: A, 407(1): $105-$ 113.

19. Hanemann, T. (2008). Influence of particle properties on the viscosity of polymer-alumina composites. Ceramics International, 34(8): 2099 - 2105.

20. Wan, W., Yang, J., Zeng, J., Yao, L. and Qiu, T. (2014). Effect of solid loading on gelcasting of silica ceramics using DMAA. Ceramics International, 40(1): 1735 - 1740.

21. Subbanna, M. and Kapur, P. C. (2002). Role of powder size, packing, solid loading and dispersion in colloidal processing of ceramics. Ceramics International, 28(4): $401-405$.

22. Jie, Z., Yan-wen, Z. O. U. and Jun, H. E. (2005). Influence of graphite particle size and its shape on performance of carbon composite bipolar plate. Journal of Zhejiang University Science A, 6(10): 1080 - 1083.

23. Iswandi, Sahari, J. and Sulong, A. B. (2011, June). Effects of different particles sizes of graphite on the engineering properties of graphites/polypropylene composites on injection molding application. Key Engineering Materials, 471: 109 - 114.

24. Thomas-Vielma, P., Cervera, A., Levenfeld, B. and Várez, A. (2008). Production of alumina parts by powder injection molding with a binder system based on high density polyethylene. Journal of the European Ceramic Society, 28(4), $763-771$.

25. Zakaria, H., Muhamad, N., Sulong, A. B. and Ibrahim, I. (2014). Moldability characteristics of 3 mol\% yttria stabilized zirconia feedstock for micro-powder injection molding process. Sains Malaysiana, 43(1): 129 - 136.

26. Kalyon, D. M., Birinci, E., Yazici, R., Karuv, B. and Walsh, S. (2002). Electrical properties of composites as affected by the degree of mixedness of the conductive filler in the polymer matrix. Polymer Engineering \& Science, 42(7): 1609 - 1617.

27. Karatas, C., Kocer, A., Ünal, H. I. and Saritas, S. (2004). Rheological properties of feedstocks prepared with steatite powder and polyethylene-based thermoplastic binders. Journal of Materials Processing Technology, 152(1): $77-83$.

28. German, R. M. and Bose, A. (1997). Injection molding of metal and ceramic. Metal Powder Industries Federation. New Jersey: John Wiley \& Sons.

29. Aggarwal, G., Smid, I., Park, S. J. and German, R. M. (2007). Development of niobium powder injection molding. Part II: Debinding and sintering. International Journal of Refractory Metals and Hard Materials, 25(3): $226-236$.

30. Olhero, S. M. and Ferreira, J. M. F. (2004). Influence of particle size distribution on rheology and particle packing of silica-based suspensions. Powder Technology, 139(1): $69-75$.

31. Han, C.D. (2007). Rheology and processing of polymeric materials. Polymer Processing, Vol. 2. Oxfort University Press.

32. Trunec, M. and Hrazdera, J. (2005). Effect of ceramic nanopowders on rheology of thermoplastic suspensions. Ceramics International, 31(6): $845-849$.

33. Amin, S. Y. M., Muhamad, N., Jamaludin, K. R., Fayyaz, A. and Yunn, H. S. (2014). Characterization of the feedstock properties of metal injection-molded WC-Co with palm stearin binder system. Sains Malaysiana, 43(1), $123-128$.

34. Bobek, J., Seidl, M., Lenfeld, P., BČhálek, L. and Ausperger, A. (2011). Rheology of composites with nature vegetal origin fibers. International Journal of Mechanical, Aerospace, Industrial, Mechatronic and Manufacturing Engineering, 5(10): 1956 - 1959.

35. Hassan, N., Ahmad, S., Muhamad, N., Omar, M. A. and Hassan, N. A. (2013). Thermoplastic natural rubber (TPNR) as a backbone polymer for metal injection molding. Sains Malaysiana, 42(12): 1787 -1791. 